Marquette University

e-Publications@Marquette

Theology Faculty Research and Publications

Theology, Department of

$1-1-2008$

\title{
In the Mirror of the Divine Face: The Enochic Features of the Exagoge of Ezekiel the Tragedian
}

Andrei Orlov

Marquette University, andrei.orlov@marquette.edu

Accepted version. "In the Mirror of the Divine Face: The Enochic Features of the Exagoge of Ezekiel the Tragedian" in The Significance of Sinai. Eds. G.J. Brooke, H. Najman, and L.T. Stuckenbruck. Brill, 2008: 183-199. DOI. (C) 2008 Brill. Used with permission. 


\title{
In the Mirror of the Divine Face: The Enochic Features of the Exagoge of Ezekiel the Tragedian
}

\author{
Andrei Orlov \\ Theology Department, Marquette University \\ Milwaukee, WI \\ "...The Lord of all the worlds warned Moses that he should \\ beware of his face. So it is written, 'Beware of his face' .... \\ This is the prince who is called ... Metatron." \\ Synopse zur Hekhalot-Literatur §§396-397.
}

\section{Introduction}

One of the important compendiums of Jewish mystical lore, a composition known to scholars as 3 Enoch or the Book of the Heavenly Palaces (Sefer Hekhalot) offers a striking re-interpretation of the canonical account of Moses' reception of Torah. In this text the supreme angel Metatron, also associated in Sefer Hekhalot with the seventh antediluvian patriarch Enoch, is depicted as the one who reveals Torah to the Israelite prophet by bringing it out of his heavenly storehouses. ${ }^{1}$ The account portrays Moses passing the revelation received from Enoch-Metatron to Joshua and other characters of the Israelite history representing the honorable chain of transmissions of

The Significance of Sinai: Traditions about Sinai and Divine Revelation in Judaism and Christianity, (2008): pg. 183-199. DOI. This article is @ Brill and permission has been granted for this version to appear in e-Publications@Marquette. Brill does not grant permission for this article to be further copied/distributed or hosted elsewhere without the express permission from Brill. 
the oral law, known to us also from the mishnaic Pirke Avot, the Sayings of the Fathers. The Hekhalot writer, however, revises the traditional mishnaic arrangement of prophets, rabbis, and sages by placing at the beginning of the chain the figure of Enoch-Metatron, viewed as the initial revealer. This choice of the primordial mediator competing with the primacy of Moses is not coincidental and in many ways serves as an important landmark in the long-lasting theological tradition that began many centuries earlier when the Second Temple was still standing. This development points to the theological competition between two heroes, the son of Jared and the son of Amram, which had ancient roots traced to the sacerdotal debates of the Second Temple era.

Recent scholarship has become increasingly cognizant of the complexity of the social, political, and theological climate of the late Second Temple period when the various sacerdotal groups and clans were competing for the primacy and authority of their priestly legacy. This competitive environment created a whole range of ideal mediatorial figures that, along with traditional mediators like Moses, also included other characters of primeval and Israelite history, such as Adam, Abel, Enoch, Noah, Shem, Melchisedek, and Abraham. Scholars now are well aware that in the late Second Temple period the sacerdotal legacy of Mosaic revelation came under fierce attack from various mediatorial trends that sought to offer a viable ideological alternative to the Mosaic stream through speculation on the preMosaic protological traditions. One such development, which has its roots in the early Enochic materials, tried to portray the seventh antediluvian patriarch as the custodian of the more ancient cultic revelation that had existed long before Moses. In this rival paradigm Enoch was depicted as an ancient mediator who received from God revelations superior to those received many centuries later by the son of Amram in the wilderness. The use of such a protological figure as Enoch does not seem coincidental since this primeval hero had been endowed with divine disclosures long before the Israelite prophet received his revelation and sacerdotal prescriptions on Mount Sinai. It is apparent that the circumstances surrounding the patriarch's reception of revelation described in the Second Temple Enochic booklets were much loftier than the circumstances of the Mosaic encounter in the biblical narrative. While Moses received Torah from 
the Lord on earth, the Enochic hero acquired his revelation in the celestial realm, instructed there by angels and God. In the biblical account the Lord descends to Moses' realm to convey his revelation to the seer, while Enoch is able to ascend to the divine abode and behold the Throne of Glory. The advantage here is clearly on the side of the Enochic hero.

Within the context of an ongoing competition, such a challenge could not remain unanswered by custodians of the Mosaic tradition. The non-biblical Mosaic lore demonstrates clear intentions of enhancing the exalted profile of its hero. This tendency detectable in the non-biblical Mosaic materials, of course, was not provoked solely by the rival Enochic developments, but rather was facilitated by the presence of a whole range of competitive exalted figures prominent in Second Temple Judaism. Still, the challenge of the pseudepigraphic Enoch to the biblical Moses cannot be underestimated, since the patriarch was the possessor of an alternative esoteric revelation reflected in the body of extensive literature that claimed its supremacy over Mosaic Torah. ${ }^{2}$

The aforementioned set of initial disadvantages in the fierce rivalry might explain why the Mosaic tradition, in its dialogue with Enochic lore and other Second Temple mediatorial developments, could not rest on its laurels but had to develop further and adjust the story of its character, investing him with an angelic and even divine status comparable to the elevated status of the rivals. One of the significant early testimonies of this polemical interaction between Mosaic and Enochic traditions has survived as a part of the drama Exagoge, ${ }^{3}$ a writing attributed to Ezekiel the Tragedian that depicts the prophet's experience at Sinai as his celestial enthronement. The text seeks to enhance the features of the biblical Moses and attribute to him some familiar qualities of the exalted figure of the seventh antediluvian patriarch Enoch. Preserved in fragmentary form in Eusebius of Caesarea's ${ }^{4}$ Praeparatio evangelica ${ }^{5}$, Exagoge 6790 reads:

Moses: I had a vision of a great throne on the top of Mount Sinai and it reached till the folds of heaven. A noble man was sitting on it, with a crown and a large scepter in his left hand. He beckoned to me with his right hand, so I approached and stood before the throne. He gave me the scepter and instructed me to sit on the great throne. Then he gave me a royal crown and 
got up from the throne. I beheld the whole earth all around and saw beneath the earth and above the heavens. A multitude of stars fell before my knees and I counted them all. They paraded past me like a battalion of men. Then I awoke from my sleep in fear.

Raguel: My friend ( $\left.\dot{\omega} \xi^{\prime} \varepsilon v \varepsilon\right)$, this is a good sign from God. May I live to see the day when these things are fulfilled. You will establish a great throne, become a judge and leader of men. As for your vision of the whole earth, the world below and that above the heavens - this signifies that you will see what is, what has been and what shall be. ${ }^{6}$

Wayne Meeks observes that, given its quotation by Alexander Polyhistor (ca. 80-40 B.C.E.), this Mosaic account can be taken as a witness to traditions of the second century B.C.E. ${ }^{7}$ Several characteristics of the narrative suggest that its author was familiar with Enochic traditions and tried to attribute some features of the story of the seventh antediluvian hero to Moses. ${ }^{8}$ This article will investigate the possible connections between the Exagoge and the Enochic tradition.

\section{Oneiromantic Dreams}

In the study of the Enochic features of the Exagoge, one must examine the literary form of this account. The first thing that catches the eye here is that the Sinai encounter is now fashioned not as a real life experience "in a body," as it was originally presented in the biblical accounts, but as a dream-vision. ${ }^{9}$ This oneiromantic perspective of the narrative immediately brings to mind the Enochic dreams-visions, ${ }^{10}$ particularly 1 Enoch 14, in which the patriarch's vision of the Kavod is fashioned as an oneiromantic experience. ${ }^{11}$

Additional proof that Moses' dream is oneiromantic in form and nature is Raguel's interpretation, which in the Exagoge follows immediately after Moses' dream-vision. The interpretation represents a standard feature of a mantic dream where the content of the received dream must be explained by an oneirocritic. Raguel serves here as such an oneirocritic-he discerns the message of the dream, telling the recipient (Moses) that his vision was positive.

It is also significant that the dream about the Sinai encounter in the Exagoge is fashioned as a vision of the forthcoming event, an 
anticipation of the future glorious status and deeds of Moses. This prophetic perspective is very common for Enochic accounts where the Sinai event is often depicted as a future event in order to maintain the antediluvian perspective of the narration. Thus, in the Animal Apocalypse (1 Enoch 85-90) Enoch receives a disclosure in his dream in which primeval and Israelite history is unfolded through distinctive symbolic descriptions involving zoomorphic imagery. In the course of the unfolding revelation Enoch beholds the vision of the sheep ascending on the lofty rock which, in the zoomorphic code of the Animal Apocalypse, symbolizes the future ascent of the Israelite prophet on Mount Sinai to receive Torah from God.

\section{Heavenly Ascent}

Another Enochic detail of the Exagoge is that Moses' ascension in a dream allows him not simply to travel to the top of the earthly mountain but, in imitation of the seventh antediluvian hero, to transcend the orbis terrarum, accessing the various extraterrestrial realms that include the regions "beneath the earth and above the heavens." The ascension vividly recalls the early Enochic journeys in dreams-visions to the upper heavens, as well as the lower regions, learning about the upcoming judgment of the sinners. ${ }^{12}$ This profile of Moses as a traveler above and beneath the earth is unknown in biblical accounts and most likely comes from the early Enochic conceptual developments. It should be noted that the imagery of celestial travel to the great throne on the mountain recalls Enoch's journeys in the Book of the Watchers to the cosmic mountain, a site of the great throne of the divine Kavod..$^{13}$ Scholars have previously noted terminological similarities in the throne language between the Enochic accounts and the Exagoge. ${ }^{14}$

\section{Angelus Interpres}

The visionary account of the prophet, which is now fashioned as a celestial journey, also seems to require the presence of another character appropriate in such settings, the angelus interpres, whose role is to assist the seer in understanding the upper reality. This new visionary dimension appears to be reflected in the figure of Raguel. ${ }^{15}$ His striking interpretive omniscience recalls the expertise of the angel 
Uriel of the Enochic accounts, who was able to help the seventh antedeluvian patriarch overcome initial fear and discern the proper meaning of the revealed things. ${ }^{16}$ That Raguel might be understood as a supernatural helper in the Exagoge is shown in his role of a direct participant in the vision whose knowledge of the disclosed things, rather unexpectedly, surpasses that of the seer and allows him to initiate the visionary into the hidden meaning of the revealed reality.

Another fact suggesting that Raguel might be an angelic interpreter is that it is very unusual in Jewish traditions that a non-Jew interprets dreams of a Jew. Howard Jacobson observes that "in the Bible nowhere does a non-Jew interpret a symbolic dream for a Jew.... Such dreams when dreamt by Jews are usually assumed to be understood by the dreamer (e.g. Joseph's dreams) or else are interpreted by some divine authority (e.g. Daniel 8)."17 It is however not uncommon for a heavenly being to discern the proper meaning of an Israelite's visions. It is therefore possible that Raguel is envisioned here as a celestial, not a human, interpreter.

In light of these considerations, it is possible that Raguel's address, which occupies the last part of the account, can be seen, at least structurally, as a continuation of the previous vision. One detail that might support such an arrangement is that in the beginning of his interpretation Raguel calls Moses $\xi^{\prime} \varepsilon v o \zeta_{1}{ }^{18}$ a Greek term which can be rendered in English as "guest." 19 Such an address might well be interpreted here as an angel's address to a human visitor attending the upper celestial realm which is normally alien to him.

\section{Esoteric Knowledge}

It has already been noted that the polemics between the Mosaic and the Enochic tradition revolved around the primacy and supremacy of revealed knowledge. The author of the Exagoge appears to challenge the prominent esoteric status of Enochic lore and the patriarch's role as an expert in secrets by underlining the esoteric character of Mosaic revelation and the prophet's superiority in the mysteries of heaven and earth. In Exagoge 85 Raguel tells the seer that his vision of the world below and above signifies that he will see what is, what has been, and what shall be. ${ }^{20}$ Wayne Meeks notes the 
connection of this statement of Raguel with the famous expression "what is above and what is below; what is before and what is behind; what was and what will be," which was a standard designation for knowledge belonging to the esoteric lore. ${ }^{21}$ Meeks draws attention ${ }^{22}$ to m. H9 $\alpha$. 2:1 where the prohibition of discussing the esoteric lore, ${ }^{23}$

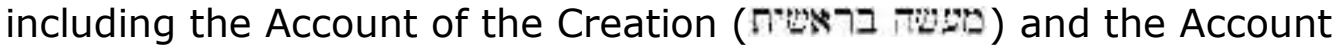

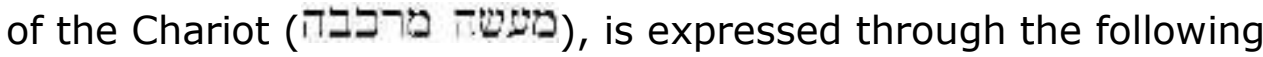
formula that closely resembles the description found in the Exagoge: "Whosoever gives his mind to four things it was better for him if he had not come into the world - what is above? what is beneath? what was beforetime? and what will be hereafter."24

It is possible that the formulae expressed in $m$. H9 $\alpha \gamma .2: 1$ and the Exagoge 85 might have their early roots in the Enochic lore where the patriarch's mediation of esoteric knowledge encompasses the important spatial dimensions of the realms above and beneath the earth as well as the temporal boundaries of the antediluvian and eschatological times. ${ }^{25}$ In the Enochic materials one can also find some designations of esoteric knowledge that might constitute the original background of the later mishnaic formulae. Thus, in the section of the Book of the Similitudes (1 Enoch 59-60) dealing with the secrets of the heavenly phenomena, the angelus interpres reveals to Enoch the secret that is "first and last in heaven, in the heights, and under the dry ground" (1 Enoch 60:11). ${ }^{26}$ These enigmatic formulations pertaining to the patriarch's role as a possessor of esoteric wisdom ${ }^{27}$ would never be forgotten in the Enochic lore and could be found even in the later rabbinic compositions dealing with the afterlife of the seventh antediluvian hero, including the already mentioned Sefer Hekhalot, which would depict Enoch-Metatron instructed by God in "the wisdom of those above and of those below, the wisdom of this world and of the world to come." 28

In light of the passage found in the Exagoge, it is possible that its author, who shows familiarity with the earlier form of the Mishnaic formula, attempts to fashion the Mosaic revelation as an esoteric tradition, similar to the Enochic lore. ${ }^{29}$ 


\section{Heavenly Counterpart}

The placement of Moses on the great throne in the Exagoge account ${ }^{30}$ and his donning of the royal regalia have been often interpreted by scholars as the prophet's occupation of the seat of the Deity. Pieter van der Horst remarks that in the Exagoge Moses become "an anthropomorphic hypostasis of God himself." 31 The uniqueness of the motif of God's vacating the throne and transferring occupancy to someone else has puzzled scholars for a long time. ${ }^{32}$ An attempt to deal with this enigma by bringing in the imagery of the vice-regent does not, in my judgment, completely solve the problem. The viceregents in Jewish traditions (for example, Metatron) do not normally occupy God's throne but instead have their own glorious chair, which sometimes serves as a replica of the divine Seat. It seems that the enigmatic identification of the prophet with the divine Form can be best explained not through the concept of a vice-regent but through the notion of a heavenly twin or counterpart. Before investigating this concept in the Exagoge, we need to provide some background for this tradition in Enochic materials.

Scholars have previously observed ${ }^{33}$ that Chapter 71 of the Book of Similitudes seems to entertain the idea of the heavenly twin of a visionary in identifying Enoch with the son of man, an enthroned messianic figure. ${ }^{34}$ For a long time scholars have found it puzzling that the son of man, distinguished in the previous chapters of the Similitudes from Enoch, is suddenly identified with the patriarch in 1 Enoch 71. James VanderKam suggests that this paradox can be explained by the Jewish notion, attested in several ancient Jewish texts, that a creature of flesh and blood could have a heavenly double or counterpart. ${ }^{35}$ As an example, VanderKam points to Jacob's traditions in which the patriarch's "features are engraved on high." ${ }^{36}$ He observes that the theme of the visionary's ignorance of his higher celestial identity is also detectable in the pseudepigraphic text the Prayer of Joseph where Jacob is identified with his heavenly counterpart, the angel Israel. VanderKam's reference to Jacob's lore is not coincidental. Conceptions of the heavenly image or counterpart of a seer take their most consistent form in Jacob's traditions. ${ }^{37}$ 
In view of the aforementioned traditions about the heavenly twins of Enoch and Jacob, it is possible that the Exagoge of Ezekiel the Tragedian also attests to the idea of a heavenly counterpart of the seer when it identifies Moses with the glorious anthropomorphic extent. We may recall that the text depicts Moses' vision of "a noble man" with a crown and a large scepter in the left hand installed on a great throne. In the course of the seer's initiation, the attributes of the "noble man," including the royal crown and the scepter, are transferred to Moses who is instructed to sit on the throne formerly occupied by the noble man. The visionary is clearly identified with his heavenly counterpart in the narrative, in the course of which the seer literally takes the place and the attributes of his upper identity. The account also underlines that Moses acquired his vision in a dream, by reporting that he awoke from his sleep in fear. Here, just as in the Jacob tradition, while the seer is sleeping on earth his counterpart in the upper realm is identified with the Kavod. ${ }^{38}$

\section{Stars and Fallen Angels}

The Exagoge depicts Moses as a counter of the stars. The text also seems to put great emphasis on the prophet's interaction with the celestial bodies that fell before Moses' knees and even paraded past him like a battalion of men. Such "astronomical" encounters are unknown in the biblical Mosaic accounts. At the same time preoccupation of the seventh antediluvian patriarch with astronomical and cosmological calculations and lore is well known and constitutes a major subject of his revelations in the earliest Enochic booklets, such as the Astronomical Book and the Book of the Watchers, in which the patriarch is depicted as the counter of stars. ${ }^{39}$ The later Enochic and Merkabah materials also demonstrate that the patriarch's expertise in counting and measuring celestial and earthly phenomena becomes a significant conceptual avenue for his future exaltation as an omniscient vice-regent of the Deity ${ }^{40}$ who knows and exercises authority over the "orders of creations." 41

The depiction of stars falling before Moses' knees also seems relevant for the subject of this investigation, especially in view of the symbolism found in some Enochic booklets where the fallen angels are often portrayed as stars. Thus, for example, the already mentioned 
NOT THE PUBLISHED VERSION; this is the author's final, peer-reviewed manuscript. The published version may be accessed by following the link in the citation at the bottom of the page.

Animal Apocalypse depicts the descent of the Watchers as the vision of stars falling down from heaven: "... I saw heaven above, and behold, a star fell from heaven ... and again I saw in the vision and looked at heaven, and behold, I saw many stars, how they came down...." (1 Enoch 86$).{ }^{42}$

If we assume that in the Exagoge stars indeed signify angels and even more precisely fallen angels, the vision of the fallen angels genuflecting before Moses' feet might again invoke the memory of some Enochic developments since the motif of angelic veneration of a seer by the fallen angels plays a significant role in some Enochic materials. The memory of this important motif is present even in the later "Enochic" compositions of the rabbinic period, for example in Sefer Hekhalot where the following tradition of Enoch's veneration by the fallen angels can be found:

R. Ishmael said: I said to Metatron: "... You are greater than all the princes, more exalted than all the angels, more beloved than all the ministers ... why, then, do they call you 'Youth' in the heavenly heights?" He answered, "Because I am Enoch, the son of Jared ... the Holy One, blessed be he, appointed me in the height as a prince and a ruler among the ministering

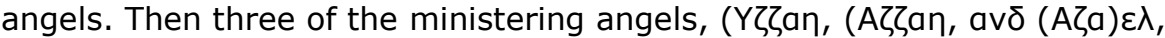
came and laid charges against me in the heavenly height. They said before the Holy One, blessed be He, 'Lord of the Universe, did not the primeval ones give you good advice when they said, Do not create man!' ... And once they all arose and went to meet me and prostrated themselves before me, saying 'Happy are you, and happy your parents, because your Creator has favored you.' Because I am young in their company and mere youth among them in days and months and years - therefore they call me 'Youth'." Synopse §§5-6. 43

It is striking that in this passage Enoch-Metatron is venerated

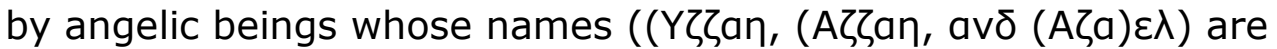
reminiscent of the names of the notorious leaders of the fallen angels found in the early Enochic lore that are rendered by the zoomorphic code of the Animal Apocalypse as the stars. The tradition of angelic veneration has rather early roots in the Enochic lore and can be found in 2 Enoch 22 where the patriarch's transformation into the heavenly counterpart, like in the Exagoge, is accompanied by angelic veneration. In this account the Lord invites Enoch to stand forever before his Face. In the course of this initiation the Deity orders the angels of heaven to venerate the patriarch. ${ }^{44}$ 
Another account of angelic veneration is found in 2 Enoch 7 where the patriarch is venerated not simply by celestial angels but the fallen ones. 2 Enoch 7:3 depicts Enoch carried by angels to the second heaven. There the patriarch sees the condemned angels kept as prisoners awaiting the "measureless judgment." Enoch's angelic guides explain to him that the prisoners are "those who turned away from the Lord, who did not obey the Lord's commandments, but of their own will plotted together and turned away with their prince and with those who are under restraint in the fifth heaven." 45 The story continues with angelic veneration. The condemned angels bow down to Enoch asking for his intercession: "Man of God, pray for us to the Lord!"46 It should be noted that, although the motif of angelic veneration has its roots in the Adamic lore, ${ }^{47}$ the theme of veneration by the fallen angels might be a peculiar Enochic development. Moreover, it seems that the initial traits of this theological development in which the fallen angels "fall before the knees" of the seventh antediluvian patriarch can be already found in the earliest Enochic booklets, including the Book of the Watchers where the fallen Watchers approach the patriarch begging him for help and intersession.

\section{Transformation of the Seer's Face}

In the Second Temple Jewish materials the transformation of a seer into his heavenly counterpart often involves the change of his bodily appearance. It may happen even in a dream as, for example, in the Similitudes' account of the heavenly counterpart where, although Enoch's journey was "in spirit," his "body was melted" and, as a result, he acquired the identity of the son of man. ${ }^{48} \mathrm{~A}$ similar change of the visionary's identity might be also discernible in the Exagoge where the already mentioned designation of Moses as $\xi^{\prime} \varepsilon v o \zeta$ occurs. Besides the meanings of "friend" and "guest," this Greek word also can be translated as "stranger." 49 If the Exagoge authors indeed had in mind this meaning of ' $\xi^{\prime} \varepsilon v o \zeta$, it might well be related to the fact that Moses' face or his body underwent some sort of transformation that altered his previous physical appearance and made him appear as a stranger to Raguel. The motif of Moses' altered identity after his encounter with the Kavod is reflected not only in Exod 34 but also in extra-biblical Mosaic accounts, including the tradition found in Pseudo-Philo's Biblical 
NOT THE PUBLISHED VERSION; this is the author's final, peer-reviewed manuscript. The published version may be accessed by following the link in the citation at the bottom of the page.

Antiquities 12:1. The passage tells that the Israelites failed to recognize Moses after his glorious metamorphosis on Mount Sinai:

Moses came down. (Having been bathed with light that could not be gazed upon, he had gone down to the place where the light of the sun and the moon are. The light of his face surpassed the splendor of the sun and the moon, but he was unaware of this). When he came down to the children of Israel, upon seeing him they did not recognize him. But when he had spoken, then they recognized him. ${ }^{50}$

The motif of the shining countenance of Moses is important for our ongoing discussion of the polemics between Enochic and Mosaic traditions that were striving to enhance the profiles of their main characters with features borrowed from the hero of the rival trend. This distinctive mark of the Israelite prophet's identity, his glorious face, which served in Biblical accounts as the undeniable proof of his encounter with God, later became appropriated in the framework of Enochic $^{51}$ and Metatron ${ }^{52}$ traditions as the chief distinguishing feature of the Enochic hero. In this new development Moses' shining face became nothing more than the later imitation of the glorious countenance of Enoch-Metatron. Thus, in Sefer Hekhalot 15B, EnochMetatron tells Moses about his shining visage: "Son of Amram, fear not! for already God favors you. Ask what you will with confidence and boldness, for light shines from the skin of your face from one end of the world to the other." 53

Here, as in the case of very few distinctive visionaries who were predestined to encounter their heavenly counterparts and to behold the Divine Face like their own reflection in a mirror, Moses too finds out that his luminous face is a reflection of the glorious face of the deity. Yet, there is one important difference: this Divine Face is now represented by his long-lasting contender, Enoch-Metatron. ${ }^{54}$

\section{Notes}

1 "Metatron brought Torah out from my storehouses and committed it to Moses, and Moses to Joshua, Joshua to the Elders, the Elders to the Prophets, the Prophets to the Men of the Great Synagogue, the Men of the Great Synagogue to Ezra the Scribe, Ezra the Scribe to Hillel the Elder ...." P. Alexander, "3 (Hebrew Apocalypse of) Enoch," The Old 
Testament Pseudepigrapha (2 vols.; ed. J. H. Charlesworth; New York: Doubleday, 1985 [1983]), 1.315; P. Schäfer, with M. Schlüter and H. G. von Mutius, Synopse zur Hekhalot-Literatur (TSAJ, 2; Tübingen: Mohr-Siebeck, 1981) §80.

${ }^{2}$ On the interaction between Enochic and Mosaic traditions, see: P. Alexander, "From Son of Adam to a Second God: Transformation of the Biblical Enoch, "Biblical Figures Outside the Bible (ed. M.E. Stone and T.A. Bergen; Harrisburg: Trinity Press International, 1998) 102111 ; idem, "Enoch and the Beginnings of Jewish Interest in Natural Science," in: The Wisdom Texts from Qumran and the Development of Sapiental Thought (eds. C. Hempel et al., BETL 159; Leuven: Peeters, 2002) 223-243; G. Boccaccini, Beyond the Essene Hypothesis: The Parting of the Ways Between Qumran and Enochic Judaism (Grand Rapids: Eerdmans, 1998); A. Orlov, The Enoch-Metatron Tradition (TSAJ, 107; Tübingen: Mohr/Siebeck, 2005) 254-303; J. VanderKam, Enoch: A Man for All Generations (Columbia: South Carolina, 1995); idem, "The Interpretation of Genesis in 1 Enoch," in: The Bible at Qumran (eds. P. W. Flint and T. H. Kim; Grand Rapids: Eerdmans, 2000) 129-148.

3 On the Exagoge of Ezekiel the Tragedian, see S. N. Bunta, Moses, Adam and the Glory of the Lord in Ezekiel the Tragedian: On the Roots of a Merkabah Text (Ph.D. Dissertation; Marquette University, 2005); J. J. Collins, Between Athens and Jerusalem (2nd ed.; Grand Rapids: Eerdmans, 2000) 224-225; M. Gaster, The Samaritans. Their History, Doctrines and Literature (London: Oxford University Press, 1925); I. Gruenwald, Apocalyptic and Merkavah Mysticism (AGJU, 14; Leiden: Brill, 1980); Y. Gutman, The Beginnings of Jewish-Hellenistic Literature (2 vols.; Jerusalem: Mosad Bialik, 1958-1963) [in Hebrew]; C. R. Holladay, "The Portrait of Moses in Ezekiel the Tragedian," SBLSP 10 (1976) 447-452; idem, Fragments from Hellenistic Jewish Authors: Vol. II, Poets (SBLTT, 30; Pseudepigrapha Series 12; Atlanta: Scholars, 1989) 439-449; P. W. van der Horst, "De Joodse toneelschrijver Ezechiel," Nederlands Theologisch Tijdschrift 36 (1982) 97-112; idem, "Moses' Throne Vision in Ezekiel the Dramatist," JJS 34 (1983) 21-29; idem, "Some Notes on the Exagogue of Ezekiel," Mnemosyne 37 (1984) 364-365; L. Hurtado, One God, One Lord: Early Christian Devotion and Ancient Jewish Monotheism (Philadelphia: Fortress Press, 1988) 58ff; H. Jacobson, "Mysticism and Apocalyptic in Ezekiel's Exagoge," ICS 6 (1981) 273-293; idem, The Exagoge of 
Ezekiel (Cambridge: Cambridge University Press, 1983); K. Kuiper, "De Ezekiele Poeta Iudaeo," Mnemosyne 28 (1900) 237-280; idem, "Le poète juif Ezéchiel," Revue des études juives 46 (1903) 48-73, 161-177; P. Lanfranchi, L'Exagoge d'Ezéchiel le Tragique:

Introduction, texte, traduction et commentaire (SVTP, 21; Leiden: Brill, 2006); W. A. Meeks, "Moses as God and King," in: Religions in Antiquity: Essays in Memory of Erwin Ramsdell Goodenough (ed. J. Neusner; Leiden: Brill, 1968) 354-371; idem, The Prophet-King: Moses Traditions and the Johannine Christology (SNT 14; Leiden: Brill, 1967); A. Orlov, "Ex 33 on God's Face: A Lesson from the Enochic Tradition," SBLSP 39 (2000) 130-147; idem, The Enoch-Metatron Tradition (TSAJ, 107; Tübingen: Mohr/Siebeck, 2005) 262-268; R. G. Robertson, "Ezekiel the Tragedian," The Old Testament Pseudepigrapha (2 vols.; ed. J. H. Charlesworth; New York: Doubleday, 1985 [1983]) 2.803-819; K. Ruffatto, "Raguel as Interpreter of Moses' Throne Vision: The Transcendent Identity of Raguel in the Exagoge of Ezekiel the Tragedian" (paper presented at the annual meeting of the SBL, Philadelphia, 22 November 2005); idem, "Polemics with Enochic Traditions in the Exagoge of Ezekiel the Tragedian," JSP 15 (2006) 195-210; E. Starobinski-Safran, "Un poète judéo-hellénistique: Ezéchiel le Tragique," MH 3 (1974) 216-224; E. Vogt, Tragiker Ezechiel (JSHRZ, 4.3; Gütersloh, 1983); M. Wiencke, Ezechielis Judaei poetae Alexandrini fabulae quae inscribitur Exagoge fragmenta (Mümster: Monasterii Westfalorum, 1931); R. Van De Water, "Moses' Exaltation: Pre-Christian?" JSP 21 (2000) 59-69. ${ }^{4}$ Eusebius preserves the seventeen fragments containing 269 iambic trimeter verses. Unfortunately, the limited scope of our investigation does not allow us to reflect on the broader context of Moses' dream in the Exagoge.

${ }^{5}$ The Greek text of the passage was published in several editions including: A.-M. Denis, Fragmenta pseudepigraphorum quae supersunt graeca (Leiden 1970) 210; B. Snell, Tragicorum graecorum fragmenta I (Göttingen 1971) 288-301; Jacobson, The Exagoge of Ezekiel, 54; Holladay, Fragments, 362-366.

${ }^{6}$ Jacobson, The Exagoge of Ezekiel, 54-55.

7 Meeks, The Prophet-King, 149. See also Holladay, Fragments from Hellenistic Jewish Authors, 2.308-12.

${ }^{8}$ Alexander, Gutman, Holladay, Meeks, Robertson, Ruffatto, and van der Horst point to various Enochic parallels in the Exagoge. For a 
preliminary analysis of the "Enochic" features of the Exagoge, see also A. Orlov, "Ex 33 on God's Face," 142-43; idem, The Enoch-Metatron Tradition, 262-268.

9 The text unambiguously points to the fact that Moses acquired his vision in a dream. In the Exagoge 82 the seer testified that he awoke from his sleep in fear.

10 Scholars have previously noted that already in early Enochic materials the patriarch is depicted as an oneiromantic practitioner who receives his revelations in dreams. Thus, when in the Book of the Watchers (1 Enoch 13:7-9a), Enoch describes one of his dream experiences, it vividly recalls the model often attested in similar cases of oneiromantic practices. The text reads: "And I went and sat down by the waters of Dan in Dan which is south-west of Hermon; and I read out the record of their petition until I fell asleep. And behold a dream $(\eta 9 \varepsilon \lambda \mu)$ came to me, and vision fell upon me, and I saw a vision of wrath..." M. Knibb, The Ethiopic Book of Enoch: A New Edition in the Light of the Aramaic Dead Sea Fragments (2 vols; Oxford: Clarendon Press, 1978) 1.45; 2.94. Other booklets of 1 Enoch also attest to the patriarch's visions as mantic dreams. Thus, when in 1 Enoch 83 and 85, the seventh antediluvian patriarch describes his revelations, the text makes explicit that these visions are received in dreams. These passages also point to the fact that Enoch's oneiromantic experiences occurred throughout his lifetime, possibly even from his early days, which the seer spent in the house of his grandfather Malalel. Later developments of this tradition reflected in the Book of Jubilees and the Book of Giants also highlight dreams as important media for the patriarch's revelations. Thus, Jub 4:19 alludes to a vision that Enoch received in a sleep-dream in which he saw all the history of humankind until its eschatological consummation: "While he [Enoch] slept he saw in a vision what has happened and what will occur - how things will happen for mankind during their history until the day of judgment." J. C. VanderKam, The Book of Jubilees (2 vols.; CSCO 510-11, Scriptores Aethiopici 87-88; Leuven: Peeters, 1989) 2.26-27.

${ }^{11}$ Although dreams are not uncommon in classic Greek drama, the content of the dream-vision suggests a Jewish rather than Greek background. On the use of dreams in Greek drama in connection with the Exagoge, see: Starobinski-Safran, "Un poète judéo-hellénistique: Ezéchiel le Tragique," 216-24; Jacobson, "Mysticism and Apocalyptic in 
Ezekiel's Exagoge," 273-93; Holladay, Fragments, 2.437.

12 See, for example, 1 Enoch 17-18.

13 The imagery of the divine throne situated on the mountain is widespread in the Book of the Watchers and can be found, for example, in 1 Enoch 18:6-8 "And I went towards the south - and it was burning day and night - where (there were) seven mountains of precious stones.... And the middle one reached to heaven, like the throne of the Lord, of stibium, and the top of the throne (was) of sapphire;" 1 Enoch 24:3 "And (there was) a seventh mountain in the middle of these, and in their height they were all like the seat of a throne, and fragrant trees surrounded it;" 1 Enoch 25:3 "And he answered me, saying: 'This high mountain which you saw, whose summit is like the throne of the Lord, is the throne where the Holy and Great One, the Lord of Glory, the Eternal King, will sit when he comes down to visit the earth for good.'" Knibb, The Ethiopic Book of Enoch, $2.104 ; 2.113$.

${ }^{14}$ Holladay, Fragments, 2.440.

15 On the figure of Raguel as a possible angelic interpreter, see also Ruffatto, "Raguel as Interpreter of Moses' Throne Vision: The Transcendent Identity of Raguel in the Exagoge of Ezekiel the Tragedian."

16 Exagoge 82: "Then I awoke from my sleep in fear." The awaking of a seer from a vision-dream in fear is a common motif in the Enochic literature. See 1 Enoch 83:6-7; 90:41-42; 2 Enoch 1:6-7 (shorter recension).

17 Jacobson, The Exagoge of Ezekiel, 92.

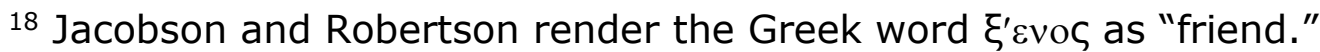

${ }^{19}$ Robertson suggests this rendering as one of the possible options. He writes that "in addition to the more common meaning of the term, there are various levels of usage, among which is the meaning 'guest."' Robertson, "Ezekiel the Tragedian," 812, note d2. See also Holladay, Fragments, 2.446.

20 Jacobson, The Exagoge of Ezekiel, 54-55.

${ }^{21}$ Sifre Zutta 84. See also 3 Enoch 10:5; 11:3.

22 Meeks, The Prophet-King, 208. See also van der Horst, "Moses' Throne Vision in Ezekiel the Dramatist," 28; C. Fletcher-Louis, "4Q374: A Discourse on the Sinai Tradition: The Deification of Moses and Early Christology," DSD 3 (1996) 236-252, esp. 246. 
NOT THE PUBLISHED VERSION; this is the author's final, peer-reviewed manuscript. The published version may be accessed by following the link in the citation at the bottom of the page.

23 G. Scholem, Major Trends in Jewish Mysticism (New York: Schocken, 1954) 74.

24 H. Danby, The Mishnah (Oxford: Oxford University Press, 1992)

213.

25 The patriarch's mediating duties comprise a whole range of spatial and chronological dimensions. His functions as mediator are not confined to a particular realm or a particular petitioner, since his clients include a range of divine, angelic, human, and composite creatures situated in the underworld as well as in heaven. In the Book of the Watchers faithful angels of heaven ask him to assist their brethren in the lower realm. In the same text he mediates on behalf of the rebellious group which includes the fallen Watchers and the Giants. Enoch's mediating activities are also not limited by specific chronological boundaries. He mediates in the generation of the Flood, but he is also expected to be a mediator and a witness of divine judgment in the eschatological period. It appears that the patriarch is predestined to mediate judgment in two significant temporal loci. One of them is the historical locus associated with the generation of the Flood; in this locale Enoch acts as an intercessor and a writer of testimonies to the Watchers, Giants and humans. The second locus is eschatological and involves Enoch's future role as witness of eschatological divine judgment.

26 Knibb, The Ethiopic Book of Enoch, 2.144.

27 On the role of the seventh antediluvian hero as an expert in the esoteric lore, see: Orlov, The Enoch-Metatron Tradition, 31-34; 48-50; 101-104; 188-200.

28 Alexander, "3 Enoch," 264.

29 The insistence of some extra-biblical Mosaic accounts on the fact that the prophet ascended to heaven might be directed towards constructing the Mosaic disclosure as an esoteric tradition in order to secure the superiority of his revelation. Wayne Meeks observes that "the most common function of ascension stories in literature of the period and milieu we are considering is a guarantee of esoteric tradition. In the apocalyptic genre the ascension of the 'prophet' or of the ancient worthy in whose name the book is written is an almost invariable introduction to the description of the secrets which the ascendant one 'saw.' The secrets, therefore, whose content may vary from descriptions of the cosmic and political events anticipated at the end of days to cosmological details, are declared to be of heavenly 
origin, not mere earthly wisdom. This pattern is the clear sign of a community which regards its own esoteric lore as inaccessible to ordinary reason but belonging to a higher order of truth. It is clear beyond dispute that this is one function which the traditions of Moses' ascension serves." Meeks adds that in the later rabbinic accounts "the notion that Moses received cosmological secrets led to elaborate descriptions of his 'heavenly journeys,' very similar to those attributed elsewhere to Enoch." Meeks, "Moses as God and King," 367-8.

30 The imagery of Moses' enthronement is not confined solely to the Exagoge account but can be found also in other extra-biblical materials. Thus, Crispin Fletcher-Louis draws attention to a parallel in the Jewish Orphica: an exalted figure, apparently Moses, is also placed on the celestial throne. C. Fletcher-Louis, All the Glory of Adam:

Liturgical Anthropology in the Dead Sea Scrolls (STDJ 42; Leiden: Brill, 2002) 137; M. Lafargue, "Orphica," The Old Testament

Pseudepigrapha (2 vols.; ed. J. H. Charlesworth; New York:

Doubleday, 1985 [1983]) 2.796-7. Orphica 26-41 reads: "...a certain unique man, an offshoot from far back of the race of the Chaldeans ... yes he after this is established in the great heaven on a golden throne. He stands with his feet on the earth. He stretches out his right hand to the ends of the ocean. The foundation of the mountains trembles within at [his] anger, and the depths of the gray sparkling sea. They cannot endure the mighty power. He is entirely heavenly, and he brings everything to completion on earth, being 'the beginning, the middle, and the end,' as the saying of the ancients, as the one waterborn has described it, the one who received [revelations] from God in aphorisms, in the form of a double law...." Lafargue, "Orphica," 2. 799-800.

${ }^{31}$ van der Horst. "Some Notes on the Exagoge," 364.

32 van der Horst, "Throne Vision," 25; Holladay, Fragments, 444.

33 See J. VanderKam, "Righteous One, Messiah, Chosen One, and Son of Man in 1 Enoch 37-71," in: The Messiah: Developments in Earliest Judaism and Christianity: The First Princeton Symposium on Judaism and Christian Origins (eds. J. H. Charlesworth et al.; Minneapolis: Fortress, 1992) 182-3; M. Knibb, "Messianism in the Pseudepigrapha in the Light of the Scrolls," DSD 2 (1995) 177-80; J. Fossum, The Image of the Invisible God: Essays on the Influence of Jewish Mysticism on Early Christology (NTOA 30; Fribourg: Universitätsverlag Freiburg Schweiz; Göttingen: Vanderhoeck \& Ruprecht, 1995) 144-5; 
Fletcher-Louis, Luke-Acts, 151 . On a heavenly double see also W. Bousset, Die Religion des Judentums im späthellenistischen Zeitalter (3d ed.; HNT 21; Tübingen: Mohr/Siebeck, 1966) 324; A. Orlov, "The Face as the Heavenly Counterpart of the Visionary in the Slavonic Ladder of Jacob," in: Of Scribes and Sages (2 vols.; ed. C.A. Evans; T\&T Clark, 2004) 2.59-76; idem, The Enoch-Metatron Tradition, 165176.

${ }^{34}$ It is important to note that in the Similitudes, the son of man is depicted as the one seated on the Throne of Glory. See 1 Enoch 62:5, 1 Enoch 69:29. Jarl Fossum observes that "in the 'Similitudes' the 'Elect One' or 'Son of Man' who is identified as the patriarch Enoch, is enthroned upon the 'throne of glory.' If 'glory' does not qualify the throne but its occupant, Enoch is actually identified with the Glory of God". Fossum further suggests that "...the 'Similitudes of Enoch' present an early parallel to the targumic description of Jacob being seated upon the 'throne of glory."' Fossum, The Image of the Invisible God, 145.

35 VanderKam, "Righteous One, Messiah, Chosen One, and Son of Man in 1 Enoch 37-71," 182-3.

36 The metaphor of "engraving" on the Kavod might signify here that the seer's identity became reflected in the divine Face, as in a mirror. 37 Besides the biblical account the traditions concerning Jacob's celestial double are also presented in the pseudepigraphical materials such as the Prayer of Joseph and the Ladder of Jacob and in several targumic texts, including Tg. Ps.-J., Tg. Neof., and Frg. Tg. In Tg. Ps.J. to Gen 28:12 the following description can be found: "He [Jacob] had a dream, and behold, a ladder was fixed in the earth with its top reaching toward the heavens ... and on that day they (angels) ascended to the heavens on high, and said, 'Come and see Jacob the pious, whose image is fixed (engraved) in the Throne of Glory, and whom you have desired to see.'" Targum Pseudo-Jonathan: Genesis (tr. M. Maher, M.S.C.; The Aramaic Bible 1B; Collegeville: The Liturgical Press, 1992) 99-100. A distinctive feature of this description is that the heavenly counterpart of Jacob, his "image," is engraved on the Throne of Glory. Engraving on the Throne indicates here an association with the Kavod since the Throne is the central part of the Kavod imagery - the seat of the anthropomorphic Glory of the Lord. Besides the tradition of engraving on the Throne, some Jewish materials point to an even more radical identification of Jacob's image 
with the Kavod. Jarl Fossum's research demonstrates that in some traditions about Jacob, his image or likeness is depicted, not simply as engraved on the heavenly throne, but as seated upon the throne of glory. Fossum argues that this second tradition is original. See Fossum, The Image of the Invisible God, 139-142.

${ }^{38}$ It cannot be excluded though that the Exagoge authors might have known the traditions of the patriarch's enthronement in heaven, similar to those reflected in the Similitudes. Also it cannot be excluded that the Mesopotamian proto-Enochic traditions, in which the prototype of Enoch, the king Enmeduranki, was installed on a throne in the assembly of gods, might have influenced the imagery found in the Exagoge. Pieter van der Horst in his analysis of the Exagoge entertains the possibility that "... in pre-Christian times there were (probably rival) traditions about Enoch and Moses as synthronoi theou; and ... these ideas were suppressed (for obvious reasons) by the rabbis." van der Horst, "Throne Vision," 27.

391 Enoch 33:2-4.

40 See Synopse $\S 66$ (3 Enoch 46:1-2).

${ }^{41}$ See 2 Enoch 40:2-4: "I know everything, and everything I have written down in books, the heavens and their boundaries and their contents. And all the armies and their movements I have measured. And I have recorded the stars and the multitude of multitudes innumerable. What human being can see their circles and their phases? For not even the angels know their number. But I have written down all their names...." Andersen, "2 Enoch," 1.164.

42 Knibb, The Ethiopic Book of Enoch, 2.196-97.

43 Alexander, "3 Enoch," 1.258-59.

44 Andersen, "2 Enoch," 1.138.

45 Andersen, "2 Enoch," 1.114.

46 Andersen, "2 Enoch," 1.114.

47 On the Adamic background of the motif of angelic veneration, see $M$. E. Stone, "The Fall of Satan and Adam's Penance: Three Notes on the Books of Adam and Eve," JTS 44 (1993) 143-156; G. Anderson, "The Exaltation of Adam and the Fall of Satan," in: Literature on Adam and Eve. Collected Essays (eds. G. Anderson, M. Stone, J. Tromp; SVTP 15; Brill: Leiden, 2000) 83-110; A. Orlov, "On the Polemical Nature of 2 (Slavonic) Enoch: A Reply to C. Bottrich," JSJ 34 (2003) 274-303. On the motif of angelic veneration in rabbinic literature see, also A. Altmann, "The Gnostic Background of the Rabbinic Adam Legends," 
JQR 35 (1945) 371-391; B. Barc, "La taille cosmique d'Adam dans la littérature juive rabbinique des trois premiers siècles apres J.-C.," $R S R$ 49 (1975) 173-85; J. Fossum, "The Adorable Adam of the Mystics and the Rebuttals of the Rabbis," Geschichte-Tradition-Reflexion.

Festschrift für Martin Hengel zum 70. Geburtstag (2 vols; eds. H. Cancik, H. Lichtenberger and P. Schäfer; Tübingen: Mohr/Siebeck, 1996) 1.529-39; G. Quispel, "Der gnostische Anthropos und die jüdische Tradition," Eranos Jahrbuch 22 (1953) 195-234; idem, "Ezekiel 1:26 in Jewish Mysticism and Gnosis," VC 34 (1980) 1-13; A. Segal, Two Powers in Heaven: Early Rabbinic Reports about Christianity and Gnosticism (SJLA 25; Leiden: Brill, 1977) 108-115.

481 Enoch $71: 11$.

49 Robertson points to this possibility. Robertson, "Ezekiel the Tragedian," 812, note d2.

$50 \mathrm{H}$. Jacobson, A Commentary on Pseudo-Philo's Liber Antiquitatum Biblicarum with Latin Text and English Translation (AGAJU 31; 2 vols.; Leiden: Brill, 1996) 1.110.

${ }^{51}$ In 2 Enoch the motif of the luminous face of the seer was transferred for the first time to the seventh antediluvian patriarch. The text tells that the vision of the divine Face had dramatic consequences for Enoch's appearance. His body endures radical changes as it becomes covered with the divine light. In Enoch's radiant metamorphosis before the divine Countenance, an important detail can be found which links Enoch's transformation with Moses' account in the Book of Exodus. In 2 Enoch 37 one learns about the unusual procedure performed on Enoch's face at the final stage of his encounter with the Lord. The text informs us that the Lord called one of his senior angels to chill the face of Enoch. The text says that the angel was "terrifying and frightful," and appeared frozen; he was as white as snow, and his hands were as cold as ice. With these cold hands he then chilled the patriarch's face. Right after this chilling procedure, the Lord informs Enoch that if his face had not been chilled here, no human being would have been able to look at him. This reference to the dangerous radiance of Enoch's face after his encounter with the Lord is an apparent parallel to the incandescent face of Moses after the Sinai experience in Exodus 34.

52 Synopse $\S 19$ (3 Enoch 15:1) depicts the radiant metamorphosis of Enoch-Metatron's face: "When the Holy One, blessed be he, took me to serve the throne of glory, the wheels of the chariot and all the 
needs of the Shekinah, at once my flesh turned to flame, my sinews to blazing fire, my bones to juniper coals, my eyelashes to lightning flashes, my eyeballs to fiery torches, the hairs of my head to hot flames, all my limbs to wings of burning fire, and the substance of my body to blazing fire." Alexander, "3 Enoch," 267.

533 Enoch 15B:5. Alexander, "3 Enoch," 304.

54 Scholars have observed that in the Merkabah tradition Metatron is explicitly identified as the hypostatic Face of God. On Metatron as the hypostatic Face of God, see A. De Conick, "Heavenly Temple Traditions and Valentinian Worship: A Case for First-Century Christology in the Second Century," The Jewish Roots of Christological Monotheism (eds. C. C. Newman, J. R. Davila, G. S. Lewis; JSJSup 63; Brill: Leiden, 1999) 329; D. Halperin, The Faces of the Chariot: Early Jewish Responses to Ezekiel's Vision (TSAJ 16; Tübingen: Mohr/Siebeck, 1988) 424-425. 